\title{
The city as forest - integrating living infrastructure, climate conditioning and urban forestry in Canberra, Australia
}

\author{
Jason Alexandra ${ }^{1,2,3^{*}}$ (D) and Barbara Norman ${ }^{2,4}$
}

\begin{abstract}
Background: Around the world cities are responding to environmental imperatives, including climate change, with diverse programs of ecologically inspired design, water re-engineering, habitat restoration and urban reafforestation. These are collectively known as living infrastructure. This paper is based on a review undertaken to identify suitable options for the use of living infrastructure in Australia's capital city, Canberra. Known as the 'bush' capital, Canberra is a medium sized city ringed with forested hills and grassy woodlands and has one of the highest rates of planted trees in the world, on a per capita basis. This paper summarises the lessons from investigating the opportunities for urban forests, and other living infrastructure being used to further enhance Canberra's amenity and climate adaptation strategies.

Results: Canberra is a planned city with a history of afforestation since its inception, but still has many opportunities to build on its status as an urban forest. Trees offer more than a backdrop to the city housing Australia's parliamentary democracy and national cultural institutions - they form a key part of the city's infrastructure. Planted forests, surrounding bushland and constructed lakes have cultural, practical and ecological values and provide multiple benefits, including climate conditioning. However, they face a range of pressures including from urban redevelopment and a changing climate, raising questions about how to sustain and enhance Canberra's living infrastructure, whilst meeting other urban policy goals. Using the case of Canberra, this paper outlines how living infrastructure - including urban forests - can contribute to meeting the twenty-first century's urban challenges.

Conclusions: The experience in Canberra demonstrate that investing in active programs of urban reafforestation and more water sensitive design provide significant opportunities to enhance cities, making them both more liveable and climate responsive. For this to occur at scale, integrated planning is needed that brings together the physical, social and ecological elements of urban systems, including through the integration of different theoretical and practical traditions including from urban planning, energy, transport and water engineering and conservation ecology. At a broader level, this involves reconceptualising the nature of the city and its socio-ecological relationships.
\end{abstract}

Keywords: Climate conditioning, Living infrastructure, Green infrastructure, Urban forests, Ecological design, Climate adaptation

\footnotetext{
* Correspondence: jason@alexandra-consulting.com

${ }^{1}$ Alexandra \& Associates Pty Ltd, 16 Homestead Road, Eltham, Victoria 3095,

Australia

${ }^{2}$ Canberra Urban and Regional Futures, University of Canberra and ANU,

Canberra, Australia

Full list of author information is available at the end of the article
}

(c) The Author(s). 2020 Open Access This article is licensed under a Creative Commons Attribution 4.0 International License, which permits use, sharing, adaptation, distribution and reproduction in any medium or format, as long as you give appropriate credit to the original author(s) and the source, provide a link to the Creative Commons licence, and indicate if changes were made. The images or other third party material in this article are included in the article's Creative Commons licence, unless indicated otherwise in a credit line to the material. If material is not included in the article's Creative Commons licence and your intended use is not permitted by statutory regulation or exceeds the permitted use, you will need to obtain permission directly from the copyright holder. To view a copy of this licence, visit http://creativecommons.org/licenses/by/4.0/. 


\section{Plain English summary}

Living infrastructure is the biological elements and ecological systems installed and managed in and around cities for multiple purposes, including functional effects like climate modification or conditioning (eg cooling in summers). Put simply, living infrastructure involves trees, shrubs, grass and open spaces (green infrastructure), rain gardens, ponds and waterways (blue infrastructure) and urban structures, like roads and buildings (grey or hard infrastructure) managed to deliver multiple benefits to people, the environment (places) and the economy (prosperity).

Living infrastructure gives tangible expression to aspirations for high-quality planning, effective decarbonising and urban innovation strategies. Functioning cities, capable of social and technical innovations are critical to meeting global environmental challenges but living infrastructure is more than an "environmental program". Networks of parks, urban forests and remodelled waterways can contribute to the revitalisation of urban areas, providing multiple social and economic benefits include enhancing equity and access to satisfying lifestyles that key into our biophilia.

This paper is based on research that focused on identifying options for living infrastructure to enhance Canberra's urban development and renewal. International experience in the planning and application of green infrastructure strategies was reviewed in order to define the opportunities and constraints to the systemic integration of nature based solutions - eg urban forests and constructed wetlands - that can deliver multiple ecosystem services, such as carbon sequestration, wastewater filtration and habitat provision.

\section{Introduction}

Cities around the world are responding to environmental imperatives, including climate change, in what has been defined as a massive global program of experimentation [1]. Diverse programs of ecologically inspired architecture and design, water re-engineering, habitat restoration and urban reafforestation are transforming urban systems using what is known collectively as green or living infrastructure to reconnect cities to the biosphere [2] and giving practical expressions to the biophilic cities ideal [3].

Canberra, Australia's capital city is increasing its use of living infrastructure, building on its history of urban planning and afforestation. This paper is based on a Canberra Urban and Regional Futures (CURF) study [4] on living infrastructure options that can contribute to the Australian Capital Territory's (ACT) ambitious climate mitigation and adaptation targets - 100\% renewable electricity by 2020 and carbon neutrality by 2045 [5].
These are likely to be achieved, including through increasing the carbon stores in urban forests [6].

Living infrastructure is defined as the biological elements and ecological systems installed and managed in and around cities for multiple purposes, including functional effects like climate modification or conditioning (eg cooling in summers) [7]. Put simply, living infrastructure involves trees, shrubs, grass and open spaces (green infrastructure), rain gardens, ponds and waterways (blue infrastructure) and urban structures, like roads and buildings (grey or hard infrastructure) managed to deliver multiple benefits to people, the environment (places) and the economy (prosperity) [4].

The CURF research [4] focused on three questions: (i) what can be learnt from international experience in the planning and application of green infrastructure strategies? (ii) How can green infrastructure enhance Canberra's urban development and renewal? (iii) What are the opportunities and constraints to the systemic integration of nature based solutions - eg urban forests and constructed wetlands - that can deliver multiple ecosystem services, such as carbon sequestration, wastewater filtration and habitat provision?

The study was based on reviewing the literature on living infrastructure and urban climate responses, and synthesising the options, benefits and issues for effective implementation. Ideas generated from the literature review were refined through feedback from policy and planning specialists. Researchers from multiple disciplines and senior urban policy professionals contributed and critiqued successive reports refining them through consultation. These iterative methods assisted in determining the local applicability of proposed initiatives to Canberra, enabling the meshing of proposals with existing government policies and priorities and the experience of previous planning, water management and forestry programs [4].

This paper is structured around several key themes that emerged from the project, including:

1. The need to understand the planning context, in order to integrate living infrastructure strategies with other policies. This is summarised in section 2;

2. Section 3 outlines the way planning for climate responsive cities ${ }^{1}$ requires integration across programs, disciplines, and governance regimes;

3. Opportunities for redesigning urban water systems to optimise urban forests, amenity and liveability are profiled in section 4;

\footnotetext{
${ }^{1}$ The term climate responsive cities is used to refer to cities that are actively responding to climate change challenges through efforts to both mitigate and adapt.
} 
4. Section 5 focuses on urban vegetation's roles in increasing stocks of living carbon and biodiversity conservation. It also examines the imperative for increasing vegetation without increasing wildfire risk; and

5. Tentative conclusions, including some key lessons from the Canberra case study are provided in section 6 .

\section{The context - planning for climate adaptation in Canberra}

After Australia's Federation in 1901, Canberra was selected as the site for the nation's capital. As a planned city it grew in an orderly and gradual fashion, filling the broad valleys with low-density suburbs whilst retaining ridges of eucalyptus woodlands. Over a century the gradual addition of suburban areas at the margins of Canberra created a sprawling, car-dependent city of approximately 400,000 residents that extends over $45 \mathrm{~km}$ north south [4]. In many respects Canberra's car based, low-rise suburbs with their detached housing are quiet typical of many suburban areas in both Australia and in other cities throughout the industrialised world, and therefore lessons derived from applying living infrastructure here may have wider relevance to many other cities.

Further, there are significant lessons arising from Canberra's history as a treed city. The parks, majestic avenues, tree lined streets, constructed lakes and ridges of bushland were central to the Griffin's original, award winning 1908 design for the capital and are defining features of the older suburbs [8]. The native woodlands and over two million planted trees and shrubs contribute to the city's unique character providing many benefits (eg cooling, shade, landscape amenity), but Canberra's trees are under pressure from urban intensification and natural attrition and the hotter and drier conditions of the twenty-first century [6]. There are also significant areas of new suburbs where there are far fewer urban trees than the older suburbs. The ACT Government has committed to increasing urban canopy cover [9] but highlights the challenge of caring for the eight hundred thousand planted trees, under the stresses of changing climatic conditions [6] including with hotter temperatures, reduced cool season rains and more intense droughts [10]. This challenge is further complicated at the urban bushland interfaces, where wildfires represent a significant risk, such that urban forests need to 'cool the city' in warmer months without escalating wildfire risks [11].

Any living infrastructure strategy needs to complement Canberra's other planning initiatives including its new, rapid transit system and urban renewal programs that are increasing urban population densities along the light rail corridors [4]. The need for mandating and incentivising living infrastructure in these urban renewal precincts is apparent because multi-rise apartments are replacing low-rise detached houses, resulting in the loss of established trees. That these require replacement if targets of increasing canopy cover are to be met, illustrates that larger scale planning policies are needed, rather than relying on adoption of individual elements on individual building sites (eg as standards or conditions imposed on construction and development projects [4].

\section{Integrated planning for multiple benefits}

Taking into account the planning context, outlined above, the CURF research emphasised six integration challenges:

1. Integrating different types of living infrastructure eg water and urban forests;

2. Integrating disciplinary, policy and governance dimensions;

3. Integrating the symbolic and material dimensions of climate adaptive cities;

4. Integrating nature in urban systems;

5. Integrating community and expert participation; and

6. Practically incorporating ideas about ecosystem services into spatial planning regimes.

Each of these challenges is outline in more detail below.

\section{Integrate across types of living infrastructure}

The integration of different types of living infrastructure at multiple scales, results in broad, interconnected systems or networks at the city scale. The different types include:

1. Water sensitive urban design (WSUD) - this refers to redesign of the urban hydrological systems to deliver multiple benefits [12]. Approaches include retention, restoration and replication of streams and riparian zones; the recycling and reuse of water such as stormwater via swales, lakes and artificial wetlands [13].

2. Urban forests, parks and street trees provide multiple ecosystem services including: (i) amenity and liveability; (ii) climate conditioning - through shade and evaporative cooling (thereby reducing energy used for artificial cooling and further contributing to climate mitigation); (iii) carbon sequestration, contributing to mitigation of climate change; and (iv) habitat $[14,15]$.

3. Green buildings including vegetated walls and rooftops for amenity, cooling and insulation and water retention [16], (but while living roofs and 
reducing hard pavement surfaces have many benefits they are not the focus of this paper).

4. Green connectors designed as links - eg biolinks between nature reserves - that are often associated with waterways, and stream networks, cycle and walk ways, disused railway lines and designated park corridors [2].

\section{Integrate technical, disciplinary and policy dimensions} Climate change has inspired multiple urban responses that vary depending with different disciplinary perspectives that includes:

1. The planned or planner's city focuses on the spatial or physical layout of cities from an urban planning perspective (see for example [17-19]);

2. The decarbonising city focuses on material and energy processes critical to city functions, for example, electricity, transport, buildings and the stock and flows of energy, goods and technologies central to reducing emissions [1];

3. The innovative city is conceived of as a forum for innovation, social foment and learning, including through education and R\&D, community engagement and the work of catalytic social groups. This focuses on the sociology and geography of cities as centres of change through political and cultural processes (see for example, [20-22]);

4. The biophilic city aims to achieve enhanced humannature relationships including through parklands, planting and urban reforestation and spans work in health, urban planning and ecology [2, 3, 23];

5. The water sensitive city focuses on reconfiguring urban hydrology building on strong civil engineering traditions $[12,24,25]$.

Given these multiple, overlapping dimensions and perspectives there are strong rationales for integrated planning approaches that aim to achieve synergies and integrated solutions [26, 27]. However, integration can be constrained by the institutionalised procedures and logics of government agencies that are given discrete responsibilities for separate elements of urban systems, including for example, water, housing, transport, energy, emergency management, parks and spatial planning [12]. Overcoming the multi-scaled political and technocratic challenges to integration requires institutional reforms [21, 26] with agency and professional entrapment remaining an impediment to transformational change $[25,28]$.

\section{Cultural and expressive roles of cities}

Living infrastructure and nature-based solutions need to be integrated with cities' political, symbolic and culturally expressive functions because through their structure, layout and design, cities perform cultural roles that exceed the sum of their functional buildings, monuments and institutional buildings [29]. These cultural dimensions are critically important to understanding cities as socio-material systems in which knowledge, politics and imagination play critical roles [30, 31].

Therefore, in an era dominated by concerns about climate change, policy responses need to mobilise citizens and civic institutions, building capacity for anticipatory policies [32]. Programs of living infrastructure can play significant roles in providing inspiration and offering tangible, material evidence of political commitment to making cities more liveable [33]. Policies promoting and enabling biophilic design can enhance experiential relationships of cities as nature rich and friendly places, enhancing health and wellbeing [3].

\section{Urban natures as novel co-produced ecosystems}

Applied to urban areas, the concept of novel ecosystem refers to the way cities generate new and different ecosystems, driven by changes in energy, nutrients, water and physical and genetic materials. New biotic and nonbiotic combinations form due to the changing conditions resulting in novel ecosystems - or novel species assemblages - that include a range of endemic and nonendemic species, including those that humans relocate, as domesticated plants and as weeds.

Cities can also be conceived of as evolving assemblages of intertwined cultural, material and ecological elements mediated through relationships and networks operating at multiple scales $[34,35]$. These assemblages are also defined as co-evolving socio-ecological systems [36, 37]. In these systems, the use of nature-based solutions is underpinned by ideas about nature [15]. Urban natures are co-produced culturally [38] and materially, existing within, and in relation to, highly modified materially and socially complex, politicised environments [31] in which objectives for urban and other ecosystems are established through institutionalised planning processes [39]. These objectives can include attempts to restore ecosystems to some idealised historic state, based on idealised, pre-development benchmarks [39]. However it may be necessary to abandon deals of ecological restoration because these may be unachievable or inappropriate given novel ecosystems and their species interactions (eg weeds and feral animals), a dynamic and changing climate and changed biogeochemical and hydrological regimes [39]. Compounding transformative processes are especially strong in and around cities where complex, non-linear feedbacks do not permit ecological restoration, even if this is desired [39]. Anthropogenic drivers of change and dynamic ecosystems responses result in inherent complexities that make ecological restoration strategies, static conservation paradigms and stationary 
hydrology models increasingly redundant, instead there needs to be a focus on iteratively steering novel coproduced ecosystem towards socially defined goals $[39,40]$.

Dispensing with the ideal of ecological restoration does not mean abandoning the use of ecologically informed design. Given the planetary pressures, planning regimes that apply ecological design, as a process of planning, iteration, revision and refinement, are needed $[39,40]$ especially for the vast areas of human dominated landscapes - or anthromes - that are the world's cities and their hinterlands [41]. Adaptive planning and ecological design concepts can be applied to shaping and steering urban, peri-urban and agricultural landscapes over time through both formal and informal planning, managing and governing processes that combine spatial planning [27], policy design [42] and the redesign of governance institutions [43].

\section{Diverse participation and utilization strategies}

Living infrastructure requires greater human involvement than 'hard' infrastructure - like roads and bridges - and given these relational dimensions, strategies need to focus on engagement and involvement of citizens, communities, and practitioners [27]. Participatory planning supports the co-production of legitimacy for strategies focused on achieving broad societal goals [44, 45] including the stewarding ecosystems [46]. The experience in Canberra is that partnering with communities, civil society and researchers enhances the prospect for success in designing and implementing living infrastructure programs.

These partnerships that steward urban strategies are critical because many residents belong to their "place" and feel these places belongs to them. Therefore, involving residents and communities is essential to promoting, designing and managing urban forests and other living infrastructure. Opportunities for involving citizens include facilitating networks of stewards, for example, landcare or friends of parks groups, and supporting citizen science initiatives like water and frog watch [47, 48]. The appreciation, involvement and experience of urban nature results in health and wellbeing benefits, including cognitive function and mental health [3, 15, 49]. Community food gardens also result in significant individual and community health benefits [50]. These wide ranging material, cultural, educational, spiritual and recreational benefits are often refereed to as ecosystem services [51].

\section{Ecosystem services and collective diffuse benefits}

Most benefits of urban forests and more 'sensitive' urban water systems accrue through diffuse processes that increase personal and community wellbeing and result in wider economic benefits through the vibrancy, attractiveness and competiveness of 'liveable' cities [27]. These benefits have been defined as ecosystem services [51], which provides a frequently used conceptual framework for thinking about and quantifying these diffuse benefits $[52,53]$. However, Laurans and Mermet [54] found that ecosystem services valuation studies rarely lead to better policy decisions, despite this being their main rationale. Given the intrinsic uncertainty and fuzziness of valuation metrics, the large number of previous studies, and uncertainty about their contributions to improved urban policy decisions [54] CURF recommended that the ACT government adopt planning guidelines and design principles rather than delaying action with more detailed ecosystem-services valuation studies [4].

\section{Living urban waters}

\section{Technologies and infrastructure for living urban water}

The infrastructure adopted in cities has a powerful bearing on urban stream networks and their aquatic ecosystems, posing particular challenges for stream restoration [55]. Impervious surfaces (roofs, roads, pavements, car parks etc) shed water rapidly, concentrating it into networks of drains and creeks changing the hydrology of urban streams, and resulting in urban runoff that is a source of nutrient pollution and sediments draining to streams, lakes and rivers [55]. However, redevelopment of drainage infrastructure can reduce these problems [56-58].

Reconceiving of stormwater as a resource can enhance urban amenity through redirecting it to constructed wetlands or urban forests $[12,56]$. A wide range of strategies and technologies for redirecting stormwater towards biologically productive uses include swales and flood outs, constructed ponds, urban wetlands and water gardens $[13,56]$. Water reuse systems that enhance the ecological diversity, biological productivity and amenity of urban ecosystems have been extensively tested [5860]. Numerous technologies suitable for transforming urban water systems should be considered proven technologies, including for pollution mitigation $[60,61]$ flood minimisation [62] and drought resilience [63].

\section{The new climate for urban water infrastructure}

Australia's urban water regimes have evolved under a highly variable climate with recurrent and severe droughts interspersed with episodic floods [64]. Climate change is likely to make extreme events more severe [65]. For Canberra, more intense storms, longer, more frequent droughts and more extreme heat are predicted that will increase wildfire risks [66]. Changing rainfall patterns are predicted to bring dryer winters and longer droughts interspersed with more intense rainfall events that increase risks of flooding [67]. Engineering designs for these changes will determine the durability and performance of water infrastructure, with good practice design aiming to minimise risks associated with changing 
rainfall regimes whilst generating a range of complementary outcomes or co-benefits, like habitat provision and urban cooling [4]. Combining networks of constructed wetlands and areas of urban forests can mitigate floods by slowing stormwater discharge and increasing infiltration that also promotes tree growth, enhancing capacity for climate conditioning and carbon sequestration [68, 69]. Tree growth in most of Australia is moisture limited [70] and therefore, concentrating runoff can enhance vegetation growth [71]. Urban flood out zones could mimic more extensive floodplain forests, like those of River Oak (Casurina cunninghamiana) and Redgum (Eucalytus camaldulensis) that occur on many southern Australian rivers [72, 73]. Urban forests growing where water and nutrients concentrate will achieve higher rates of carbon sequestration and provide more effective cooling through increased rates of evapotranspiration in comparison with surrounding rain fed vegetation. The problems of stormwater carrying nutrient and sediment to streams can be transformed into solutions that provide functional and aesthetic resources. Knowledge of these opportunities has informed Canberra's legislated code for water-sensitive urban design that has applied to new urban development since 2009 [12]. This code has resulted in stormwater storages, swales and wetlands that increase urban stormwater reuse in newer suburbs, but challenges remain in retrofitting stream networks in established areas [12].

\section{Climate conditioning in Canberra}

Canberra's street trees and urban forests provide significant climate conditioning through their cooling effects [7]. Heat mapping of Canberra during summer heatwaves demonstrates significant differences in exposure to heat stress, with less treed outer areas significantly hotter during periods of extreme heat compared with inner Canberra that receives significant cooling from its established urban vegetation [7].

Urban trees and lakes can result in substantive cooling at the city scale [74] with evidence of urban vegetation reducing heat island effects at the scale of emerging mega cities $[75,76]$ and even small pockets of trees can reduce extreme heat [77].

The climate conditioning benefits of urban trees derive from reducing heat - and therefore the health and energy use consequences of hotter cities - and from improving thermal conditions during cold conditions [78]. Vegetation reduces wind speed and wind chill, thereby reducing heat loss from buildings, lowering energy use for heating - a $10 \%$ increase in urban trees reduces heating and cooling energy use by between 5 and 10\% [78]. For Canberra, reducing energy consumed has both climate and equity dimensions, because poorer residents pay a higher proportion of the income on heating and cooling [4].

The CURF study [4] resulted in advice to the ACT Government that impacts of extreme heat and urban heat island effects could be reduced by:

1. Urban forestry and landuse planning regimes that maintain appropriate ratios of treed areas to hard surface areas (car parks, roads and buildings);

2. Channelling stormwater runoff to urban forests, thereby increasing their evapo-transpiration and thus cooling impacts;

3. Using vegetated or living roofs on suitable buildings [16]; and developing more lakes, ponds and wetlands that provide cooling services [74]; and

4. Planting large canopy irrigated shade trees into urban precincts to provide cooling during extreme conditions [4].

\section{Living carbon and urban forests Urban forests for amenity, health and wellbeing}

Australia had several pioneering advocates of urban forestry, including PA Yeoman's [79] with his book 'The City Forest'. John French also advocated for urban forestry in 1970s and 1980 [80, 81]. Almost a generation later there is a pronounced revival of urban forestry in Australia [82]. Local governments in Adelaide, Brisbane, Melbourne and Sydney have committed to ambitious targets for increasing canopy cover - ranging between 25 and $40 \%$ with target dates from 2031 to 2050 - with their efforts supported by applied R\&D and an urban forest workbook - "How To Grow an Urban Forest - A tenstep guide to help councils save money, time and share practical knowledge" [83].

The revival in interest in urban forestry is due to an increasing focus on accelerating the transition to more nature-friendly and climate adaptive cities [1-3]. This is resulting in an active re-evaluation of the social, environmental and economic benefits of urban trees - from street trees through to major urban forests. Urban trees are being seen as functionally productive with benefits often defined as ecosystem services. These include air filtration (removal of gaseous and particulate pollutants), microclimate regulation (mainly evapotranspirationcooling), noise reduction, rainwater infiltration, waste treatment, carbon sequestration and recreational and cultural values $[14,51]$.

Urban trees and forests are recognised for multiple benefits [84] with numerous efforts to more clearly articulate and quantify their specific benefits. These include studies on:

1. Micro climate regulations [76]

2. Reducing in air pollution [15] 
3. Carbon sequestration [85]

4. Urban amenity [86]

5. Timber, biomass and bioenergy production [87]

6. Biodiversity habitats $[2,15,88]$

7. Increasing property values [89], and therefore property based rates and taxes to municipal authorities, and

8. Educational, recreational, health and well-being benefits $[15,90]$.

Various valuation studies have attempted to quantify the cost and benefits of urban trees, including McPherson et al [91] who valued street and park trees in five US cities finding positive returns that ranged from $\$ 1.37$ to $\$ 3.09$ for each dollar spent. Given these positive benefits, urban forests deserve institutional support, like other forms of urban infrastructure, with long-term commitment by government agencies the most effective way of advancing urban forestry [92].

\section{Enhancing and quantifying living carbon in Canberra} Canberra's urban tree programs began in the 1920s resulting in an urban forest of over 200 species [93]. These are delivering significant energy savings, reducing carbon emissions and sequestering carbon [94]. This has been assessed using a detailed model and inventory- the Decision Information System to support the Management of Urban Trees (DISMUT) - using trees censuses starting in the 1990s, coupled with health, growth and yield models [95].

The ACT Governments Climate Change Adaptation Strategy [9] aims to sequester more carbon through new urban forests and replacement plantings. This can be measured with the DISMUT model [95]. The Government is also promoting options for integrating trees and built infrastructure (such as residential and commercial buildings) in ways that maximise passive and active solar energy gains [6].

The ACT Government is the custodian of one of Australia's foremost planned and documented urban forest $[93,95]$ providing opportunities to become a leader in urban forestry education, R\&D, scholarship and tourism. These opportunities are built on historical plantings - including the street trees and parks, the national arboretum, and the botanic gardens - and the natural regeneration of the ridgelines and reserves [4].

\section{Urban trees - enhancing biodiversity}

Urbanisation is influencing the survival of many species, but various strategies are aiming to enhance biodiversity in and around cities [96]. Efforts to develop more systematic approaches to conservation planning have historically focused on identifying priorities for the conservation estate $[97,98]$ yet it is increasingly recognised that conservation management across all tenures is required to achieve biodiversity conservation goals [99]. Furthermore, the highly modified anthropogenic biomes or anthromes - including urban and agricultural areas that have been fundamentally reshaped to meet human needs - occupy over half the world's terrestrial landscapes [41]. However, these highly modified landscapes have conversation values $[15,41,99]$ and numerous initiatives are contributing through revegetation, habitat linkages, and engaging citizens in action $[48,96]$.

With the increasing focus on urban biodiversity conservation, there is a need for reconceiving of biolinks and connectivity in and through urban areas, including scaling up from gardens $[100,101]$. Cities are nested in networks of ecosystem relationships, with biodiversity integral to their functioning [102]. Open space in and around cities, benefits humans and other organisms [2, $3]$ and for example, large trees play important roles as keystone structures in urban landscapes, increasing bird diversity [88]. Urban areas contribute to meso-scale networks of habitat connectivity [2]. Examples include Stockholm's networks of lakes and forests, Melbourne's Yarra River corridor of contiguous parks from the city centre to the River's headwaters, and Canberra's rings of urban parks and woodlands [4]. These provide useful examples of bioregional habitat connectivity through metropolitan areas.

\section{Designing living infrastructure to minimise bushfire risk}

Human burning of Australian landscapes has a long and proud tradition [103] but ideas about biophilia rarely extend to welcoming wildfires as part of nature.

In contemporary Australia, wildfires are a significant threat, particularly at the suburban-bushland interface [104]. Catastrophic fires occurred in Canberra in 2003 with property loss amplified due to the combination of suburbs surrounded by flammable farmland, bushland and pine plantations [104]. Wildfire risks are increasing due to climate change [105] with land use planning and management strategies centrally important to risk reduction [106, 107]. Greater use of preventative landuse planning has been recommended in 16 post fire inquiries since 1939 [11]. With deepening concerns about catastrophic wild fires [108-110] these kinds of warnings should be heeded when planning the expansion of urban forests.

Managing fire risks on Canberra's urban-bushland interface, requires integration of the technical and social aspect of fire risk reduction across multiple tenures [110]. Improved building and land management standards can reduce fire impacts [111] as does the location, spatial distribution, density and flammability of buildings [112]. Fuel reduction zones and shaded fuel breaks can reduce the spread of fires $[113,114]$ and fuel reduction 
burning can reduce fuel loads [107] especially when targeted to protecting built assets, like houses, rather than generalised landscape scale fuel reduction strategies [115].

In the aftermath of the Canberra fires, Bartlett [104] recommended increasing the distance between pine plantations and suburbs. Fuel reduction zones could be planted with deciduous broadleaves species that modify fire behaviour and slow fire spread [116, 117] because these species have lower flammability than pines or eucalyptus [4]. Flammability characteristics and fire risk consideration have major implications for species selected for use in fuel reduction zones, parks, roadsides and gardens in fire prone areas.

\section{The biodiverse and biophilic cities movement}

Canberra's renewed commitments to living infrastructure draw on the lessons from its legacy of planning and afforestation and as a result it has potential to be leader in the biophilic cities movement [4, 22, 33]. This movement is emerging globally focused on conservation, restoration and sustainability of cities as coupled human-natural systems $[2,3]$. In many practical ways it can draw on the experience of re-wilding, in or close to cities $[118,119]$ and on more actively adopting peer-to-peer learning models and extracting lessons from international comparisons of cities transitioning towards sustainability [27].

Biophilia involves spanning nature-cultural divides [3] in our relationships and conceptualisation of nature, and the nature of the city [12]. This means reconceiving of urban areas not just as remnants of pre-existing ecosystems that occurred before suburbs engulfed the countryside but as dynamic, hybrid or novel ecosystems, driven by changes in fundamental processes of nutrient, genetic material, energy balances and water flows $[39,40,120]$. Therefore, there remain a fundamental need for conceptual clarification about if, when and whether, and at what scale biodiversity conservation strategies involve efforts at restoration, and/or the active creation of hybrid or novel ecosystems [39]. Standish et al [15] identify options along a spectrum that includes (i) conserving and restoring predominantly 'natural' areas; (ii) restoring remnants habitat, and (iii) actively managing novel ecosystems, including gardens for biodiversity.

While many cities aim to enhance biodiversity conservation, these goals remain open to differing interpretation of ecological theory and different practices, resulting in a need to clarify fundamental ideas about biodiversity conservation, ecological restoration and designer ecosystems in the Anthropocene, with its unprecedented changes in the drivers and conditions affecting species and ecosystems $[39,40,120]$ including in and around cities.

\section{Conclusions}

This paper summarises how Canberra has been able to draw on its experience of having extensive parklands, lakes and urban forests as the basis for understanding the value of living infrastructure. By combining this legacy with renewed commitments to further investments, it is possible to envisage Canberra becoming a twenty-first century exemplar of a climate responsive, biophilic city, providing healthy, high quality lifestyles to its inhabitants.

This paper's case study of Canberra documents how urban reafforestation and more water sensitive designs provide many significant opportunities to enhance both the physical and social fabric of cities, making them more liveable and climate responsive. The review is offered, not so as to promote the idea that the exact models adopted in Canberra can be replicated in other cities, but as a starting point, to inspire other cities, particularly medium sized cities, (and their urban planners and researchers) to investigate options suited to their circumstances.

Four key lessons emerge from Canberra's experience.

First, existing examples of living infrastructure are useful and important in building support for the case for renewed metropolitan-scale investment because they provide tangible experience of the value of these to the inhabitants of a city. These benefits need to be widely understood and communicated.

Secondly, Canberra's experience demonstrates that integrated planning modes are required to bring together the different theoretical and practical traditions involved. In order to integrate the physical, social and ecological elements of urban systems, these need to involve urban planners, energy, transport and water engineers, parks and gardens and conservation ecologists.

Thirdly, the social dimensions, including broad and sustained partnerships play critical roles. Canberra's living infrastructure initiatives are a result of the ACT Government's commitment to partnering with residents, industries and researchers in responding to climate imperatives with adaptation and mitigation measures.

Fourthly, living infrastructure is much more than an urban "environmental program" and should not be limited and pigeonholed in this way. It needs support across the professions and agencies responsible for the functioning of the urban system.

Living infrastructure can give tangible expression to aspirations for high-quality planning, effective decarbonising and urban innovation strategies. Networks of parks, urban forests and remodelled waterways can contribute to the revitalisation of urban areas, providing multiple social and economic benefits, including enhancing equity and access to satisfying lifestyles that key into our biophilia. Functioning cities, capable of social and technical innovations are critical to meeting global environmental challenges. Further international comparison and case studies documenting individual cities will be useful in sharing of lessons and in accelerating the adoption of living infrastructure innovations. 


\section{Acknowledgments}

Jason Alexandra acknowledges those who contributed to the original CURF study on which this paper is based. Jason Alexandra was the lead author with support and assistance from Barbara Norman (project manager), Will Steffen (advisor), Bill Maher (advisor), David Flannery (photos and layout) and Alison Foulsham (editorial assistant).

\section{Authors' contributions}

Jason Alexandra conducted the review and was lead author on the CURF report. He also drafted and edited the final manuscript. Barbara Norman designed and managed the CURF Living Infrastructure project and also read and approved the final manuscript. The author(s) read and approved the final manuscript.

\section{Funding}

ACT Government funded the initial CURF study into Living Infrastructure, but no funding was received or used in producing this paper.

\section{Availability of data and materials}

Not applicable.

\section{Ethics approval and consent to participate}

Not applicable.

\section{Consent for publication}

Not applicable.

\section{Competing interests}

The authors declare that they have no competing interests.

\section{Author details}

'Alexandra \& Associates Pty Ltd, 16 Homestead Road, Eltham, Victoria 3095, Australia. ${ }^{2}$ Canberra Urban and Regional Futures, University of Canberra and ANU, Canberra, Australia. ${ }^{3}$ RMIT, School of Global, Urban and Social Studies, Melbourne, Victoria 3001, Australia. ${ }^{4}$ Urban and Regional Planning, University of Canberra, Canberra, Australia.

Received: 5 June 2019 Accepted: 16 July 2020

Published online: 23 July 2020

\section{References}

1. Broto VC, Bulkeley H. A survey of urban climate change experiments in 100 cities. Glob Environ Chang. 2013;23(1):92-102.

2. Andersson E, Barthel S, Borgström S, Colding J, Elmqvist T, Folke C, Gren $\AA$. Reconnecting cities to the biosphere: stewardship of green infrastructure and urban ecosystem services. Ambio. 2014;43(4):445-53.

3. Beatley T, Newman P. 2013 Biophilic cities are sustainable, Resil Cities Sustain. 2013;5(8):3328-45. https://doi.org/10.3390/su5083328.

4. Alexandra J, Norman B, Steffen W, Maher W. Planning and Implementing Living Infrastructure in the Australian Capital Territory - Final Report. Canberra: Canberra urban and regional futures, University of Canberra; 2017.

5. Kemp L, Sackett P, Jotzo F. Sub-National Climate Policies: how does the ACT compare? Canberra: ACT Climate Change Council; 2015. https://www. environment.act.gov.au/_data/assets/pdf file/0011/799580/ACT_CCC-2015Report_Nov2015-for-web.pdf. Accessed 21 Feb 2019

6. ACT Government 2018 Canberra's Living infrastructure - Information Pape https://www.environment.act.gov.au/_data/assets/pdf_file/0011/1170965/ Canberra-Living-Infrastructure-Information-paper-2018.pdf. Accessed 28 Feb 19.

7. Meyers J, Devereux D, Van Niel T, Barnett G. Mapping surface urban heat in Canberra. Australia: CSIRO; 2017.

8. Ramsey J. Lake Burley Griffin: Losing an Inspired Vision Australian garden history. https://s3.amazonaws.com/academia.edu.documents/34446319/ Canberra_Lake_paper.pdf?AWSAccessKeyld=AKIAIWOWYYGZ2Y53UL3 A\&Expires $=1558418974 \&$ Signature $=F \% 2 B 5 C a R K f a D 3 J G Z 4 U A I Q m Q 9 A \% 2$ BHaQ\%3D\&response-content-disposition=inline\%3B\%20filename\%3DLake_ Burley Griffin Losing and Inspired.pdf. Accessed 2 Apr 2019.

9. ACT Government 2016 ACT Climate Change Adaptation Strategy https:// www.environment.act.gov.au/_data/assets/pdf file/0004/912478/ACTClimate-Change-Adaptation-Strategy.pdf. Accessed 28 Feb 2019.
10. BOM and CSIRO 2018 State of the Climate 2012. http://www.bom.gov.au/ state-of-the-climate/State-of-the-Climate-2018.pdf/. Accessed 28 Apr 2019.

11. Norman B, Weir J, Sullivan K, Lavis J. Planning and bushfire risk in a changing climate; 2014

12. Alexandra J. The city as nature and the nature of the city - climate adaptation using living infrastructure - governance and integration challenges. Aust J Water Resour. 2017;21:63-76. https://doi.org/10.1080/ 13241583.2017.1405570

13. Wong TH. An overview of water sensitive urban design practices in Australia. Water Pract Technol. 2006;1(1):wpt2006018.

14. Jim CY, Chen WY. Ecosystem services and valuation of urban forests in China. Cities. 2009;26(4):187-94.

15. Standish RJ, Hobbs RJ, Miller JR. Improving city life: options for ecological restoration in urban landscapes and how these might influence interactions between people and nature. Landsc Ecol. 2013;28(6):1213-21.

16. Coutts AM, Daly E, Beringer J, Tapper NJ. Assessing practical measures to reduce urban heat: green and cool roofs. Build Environ. 2013;70:266-76.

17. Wilson E. Adapting to climate change at the local level: the spatial planning response. Local Environ. 2006;11(6):609-25.

18. Gill SE, Handley JF, Ennos AR, Pauleit S. Adapting cities for climate change: the role of the green infrastructure. Built Environ. 2007:33(1):115-33.

19. Measham TG, Preston BL, Smith TF, Brooke C, Gorddard R, Withycombe G, Morrison C. Adapting to climate change through local municipal planning: barriers and challenges. Mitig Adapt Strateg Glob Chang. 2011;16(8):889909.

20. Bettencourt LM, Lobo J, Helbing D, Kühnert C, West GB. Growth, innovation, scaling, and the pace of life in cities. Proc Natl Acad Sci. 2007;104(17):7301-6.

21. Anguelovski I, Carmin J. Something borrowed, everything new: innovation and institutionalization in urban climate governance. Curr Opin Environ Sustain. 2011:3(3):169-75.

22. Leichenko R. Climate change and urban resilience. Curr Opin Environ Sustain. 2011:3(3):164-8.

23. Beatley T. Biophilic cities: integrating nature into urban design and planning. Washington: Island Press; 2011

24. Ferguson BC, Frantzeskaki N, Brown RR. A strategic program for transitioning to a water Sensitive City. Landsc Urban Plan. 2013;117:32-45.

25. Rijke J, Farrelly M, Brown R, Zevenbergen C. Configuring transformative governance to enhance resilient urban water systems. Environ Sci Policy. 2013;25:62-72.

26. Carmin J, Dodman D, Chu E. Urban climate adaptation and leadership: from conceptual understanding to practical action (No. 2013/26). OECD: Publishing; 2013.

27. Norman B. Sustainable pathways for our cities and regions: planning within planetary boundaries. London, NY: Routledge; 2018.

28. Brown R, Ashley R, Farrelly M. Political and professional agency entrapment: an agenda for urban water research. Water Resour Manag. 2011;25(15): 4037-50.

29. DeLanda M. A New Philosophy of Society: Assemblage Theory and Social Complexity. New York: Continuum; 2006.

30. Amin A, Thrift N. Cities - reimagining the urban. Oxford: Blackwell; 2002

31. Heynen N, Kaika M, Swyngedouw E. Urban political ecology: politicizing the production of urban natures. In: Swyngedouw MK, Heynen N, editors. In the Nature of Cities. New York: Routledge; 2006. p. 1-20.

32. Boyd E, Nykvist B, Borgström S, Stacewicz IA. Anticipatory governance for social-ecological resilience. Ambio. 2015:44(1):149-61.

33. Ignatieva M, Ahrné K. Biodiverse green infrastructure for the 21st century: from "green desert" of lawns to biophilic cities. J Archit Urban. 2013;37(1):1-9.

34. Anderson B, McFarlane C. Assemblage and geography. Area. 2011;43(2):124-7.

35. Fuller C. Urban politics and the social practices of critique and justification conceptual insights from French pragmatism. Prog Hum Geogr. 2013;37(5): 639-57.

36. Folke C, Carpenter S, Elmqvist T, Gunderson L, Holling CS, Walker B. Resilience and sustainable development: building adaptive capacity in a world of transformations. Ambio. 2002:31:437-40.

37. Gual MA, Norgaard RB. Bridging ecological and social systems coevolution: a review and proposal. Ecol Econ. 2010;69(4):707-17.

38. Castree N. Making sense of nature. Oxford: Routledge; 2014.

39. Ross MRV, Bernhardt ES, Doyle MW, Heffernan JB. Designer ecosystems: incorporating design approaches into applied ecology. Annu Rev Environ Resour. 2015:40:419-43. https://doi.org/10.1146/annurev-environ-121012100957. 
40. Alexandra J. Australia's landscapes in a changing climate - caution, hope, inspiration, and transformation CSIRO publishing. Crop \& Pasture Science. 2012;63:215-31. https://doi.org/10.1071/CP11189.

41. Ellis EC. Sustaining biodiversity and people in the world's anthropogenic biomes. Curr Opin Environ Sustainability. 2013. https://doi.org/10.1016/j. cosust.2013.07.002

42. Sterner T, Barbier EB, Bateman I, van den Bijgaart I, Crépin A-S, Edenhofer O, Fischer C, Habla W, Hassler J, Johansson-Stenman O, Lange A, Polasky S, Rockström J, Smith HG, Steffen W, Wagner G, Wilen JE, Alpízar F, Azar C, Carless D, Chávez C, Coria J, Engström G, Jagers SC, Köhlin G, Löfgren Å, Pleijel H, Robinson A. Policy design for the Anthropocene. Nat Sustainability. 2019;2(1):14-21. https://doi.org/10.1038/s41893-018-0194-X.

43. Hassenforder E, Barone S. State of the art review: institutional arrangements for water governance. Int J Water Resour Dev. 1-25. https://doi.org/10.1080/ 07900627.2018 .1431526

44. Walker B, Carpenter S, Anderies J, Abel N, Cumming GS, Janssen M, Lebel L, Norberg J, Peterson GD, Pritchard R. Resilience Management in Socioecological Systems: a working hypothesis for a participatory approach Conserv Ecol. 2002;6(1):14 http://www.consecol.org/vol6/iss1/art14/.

45. Alston M, Whittenbury K. Climate change and water policy in Australia's irrigation areas: a lost opportunity for a partnership model of governance. Environmental Politics. 2011;20(6):899-917.

46. Chapin FS, Carpenter SR, Kofinas GP, Folke C, Abel N, Clark WC, Olsson P, Smith DMS, Walker B, Young OR, Berkes F. Ecosystem stewardship: sustainability strategies for a rapidly changing planet. Trends Ecol Evol. 2010;25(4):241-9.

47. Campbell A. Landcare. Melbourne: Penguin Books; 1994.

48. Campbell A, Alexandra J, Curtis D. Reflections on four decades of land restoration in Australia rangelands. Journal. 2018:39:405-16. https://doi.org/10.1071/RJ17056.

49. Tzoulas K, Korpela K, Venn S, Yli-Pelkonen V, Kaźmierczak A, Niemela J, James P. Promoting ecosystem and human health in urban areas using green infrastructure: a literature review. Landsc Urban Plan. 2007:81(3):167-78.

50. Wakefield S, Yeudall F, Taron C, Reynolds J, Skinner A. Growing urban health: community gardening in south-East Toronto. Health Promot Int. 2007;22(2):92-101.

51. Bolund P, Hunhammar S. Ecosystem services in urban areas. Ecol Econ. 1999;29(2):293-301.

52. Nelson E, Mendoza G, Regetz J, Polasky S, Tallis H, Cameron D, Chan K, Daily GC, Goldstein J, Kareiva PM, Lonsdorf E. Modeling multiple ecosystem services, biodiversity conservation, commodity production, and tradeoffs at landscape scales. Front Ecol Environ. 2009;7(1):4-11.

53. Gómez-Baggethun E, Barton DN. Classifying and valuing ecosystem services for urban planning. Ecol Econ. 2013;86:235-45.

54. Laurans $Y$, Mermet L. Ecosystem services economic valuation, decisionsupport system or advocacy? Ecosyst Serv. 2014;7:98-105.

55. Walsh CJ, Fletcher TD, Ladson AR. Stream restoration in urban catchments through redesigning stormwater systems: looking to the catchment to save the stream. J N Am Benthol Soc. 2005;24(3):690-705.

56. Grant SB, Saphores JD, Feldman DL, Hamilton AJ, Fletcher TD, Cook PL, Stewardson M, Sanders BF, Levin LA, Ambrose RF, Deletic A. Taking the "waste" out of "wastewater" for human water security and ecosystem sustainability. Science. 2012;337(6095):681-6.

57. US EPA 2016. https://www.epa.gov/green-infrastructure/what-greeninfrastructure. Accessed 4 July 2016.

58. Hsieh CH, Davis AP. Evaluation and optimization of bioretention media for treatment of urban stormwater runoff. J Environ Eng. 2005;131(11):1521-31.

59. Shutes RBE. Artificial wetlands and water quality improvement. Environ Int. 2001;26(5):441-7.

60. Shutes RBE, Revitt DM, Mungur AS, Scholes LNL. The design of wetland systems for the treatment of urban run off. Water Sci Technol. 1997;35(5):19-25.

61. Qingan W, Yong R, Jun Q, Qiujin Z. Biological Community in Constructed Wetland Pond-bed System of living water garden in Chengdu. Chongqing Environ Sci. 2001;2:018.

62. Guo Y. Hydrologic design of urban flood control detention ponds. J Hydrol Eng. 2001;6(6):472-9.

63. US EPA 2016b. https://www.epa.gov/green-infrastructure/greeninfrastructure-climate-resiliency. Accessed 4 July 2016.

64. Kiem AS, Verdon-Kidd DC. The importance of understanding drivers of hydroclimatic variability for robust flood risk planning in the coastal zone. Aust J Water Resour. 2013:17:2
65. CSIRO. Climate change and variability in SE Australia - A synthesis of Phase 1 of South Eastern Australia climate Initaitive (SEACI). Melbourne: CSIRO; 2010.

66. Moritz MA, Batllori E, Bradstock RA, Gill AM, Handmer J, Hessburg PF, Leonard J, McCaffrey S, Odion DC, Schoennagel T, Syphard AD. Learning to coexist with wildfire. Nature. 2014;515:58.

67. CSIRO, 2012. SEACI phase 2 synthesis report, Climate and water availability in south-eastern Australia. http://www.seaci.org/publications/documents/ SEACl-2Reports/SEACI_Phase2_SynthesisReport.pdf. Accessed 4 Apr 2019.

68. Bartens J, Day SD, Harris JR, Dove JE, Wynn TM. Can urban tree roots improve infiltration through compacted subsoils for stormwater management? J Environ Qual. 2008:37(6):2048-57.

69. Escobedo FJ, Kroeger T, Wagner JE. Urban forests and pollution mitigation: analyzing ecosystem services and disservices. Environ Pollut. 2011;159(8): 2078-87.

70. Donohue RJ, Roderick ML, McVicar TR. Assessing the differences in sensitivities of runoff to changes in climatic conditions across a large basin. J Hydrol. 2011;406(3-4):234-44. https://doi.org/10.1016/j.jhydrol.2011.07.003.

71. Xiao Q, McPherson EG, Simpson JR, Ustin SL. Rainfall interception by Sacramento's urban forest. J Arboriculture. 1998;24:235-44.

72. McGregor HW, Matthew CJ. Lunt I D Did early logging or changes in disturbance regimes promote high tree densities in river red gum forests? Aust J Botan. 2016;64:530-8. https://doi.org/10.1071/BT16025.

73. Briggs SV, Maher MT. Litter fall and leaf decomposition in a river red gum (Eucalyptus camaldulensis) swamp. Aust J Bot. 1983;31(3):307-16.

74. Žuvela-Aloise M, Koch R, Buchholz S, Früh B. Modelling the potential of green and blue infrastructure to reduce urban heat load in the city of Vienna. Clim Chang. 2016;135(3-4):425-38.

75. Li J, Song C, Cao L, Zhu F, Meng X, Wu J. Impacts of landscape structure on surface urban heat islands: a case study of Shanghai, China. Remote Sens Environ. 2011;115(12):3249-63.

76. Chen $X \mathrm{~L}$, Zhao HM, Li PX, Yin ZY. Remote sensing image-based analysis of the relationship between urban heat island and land use/cover changes. Remote Sens Environ. 2006:104(2):133-46.

77. Shashua-Bar L, Hoffman ME. Vegetation as a climatic component in the design of an urban street: an empirical model for predicting the cooling effect of urban green areas with trees. Energy Buildings. 2000;31(3):221-35.

78. McPherson EG, Nowak D, Heisler G, Grimmond S, Souch C, Grant R, Rowntree R. Quantifying urban forest structure, function, and value: the Chicago urban Forest climate project. Urban Ecosyst. 1997;1(1):49-61.

79. Yeomans PA. The city forest: the Keyline plan for the human environment revolution. Sydney: Keyline; 1971

80. French JRJ. The concept of urban forestry. Aust For. 1975;38(3):177-82.

81. French JR. Planning for urban forestry at the municipal level. Urban Policy Res. 1983;1(3):11-5.

82. Davison A, Kirkpatrick J. Re-inventing the urban Forest: the rise of arboriculture in Australia. Urban Policy Res. 2014;32(2):145-62. https://doi. org/10.1080/08111146.2013.832669.

83. Horticultural Innovations Australia 2019 - "How To Grow an Urban Forest A ten-step guide to help councils save money, time and share practical knowledge" http://202020vision.com.au/help-hub/how-to-create-an-urbanforest/. Accessed 1 Mar 2019.

84. Nowak DJ. Institutionalizing urban forestry as a "biotechnology" to improve environmental quality. Urban Forestry Urban Greening. 2006;5(2):93-100.

85. Nowak DJ, Crane DE. Carbon storage and sequestration by urban trees in the USA. Environ Pollut. 2002;116(3):381-9.

86. Price C. Quantifying the aesthetic benefits of urban forestry. Urban Forestry Urban Greening. 2003;1(3):123-33.

87. MacFarlane DW. Potential availability of urban wood biomass in Michigan: implications for energy production, carbon sequestration and sustainable forest management in the USA. Biomass Bioenergy. 2009; 33(4):628-34.

88. Stagoll K, Lindenmayer DB, Knight E, Fischer J, Manning AD. Large trees are keystone structures in urban parks. Conserv Lett. 2012;5(2):115-22.

89. Tyrväinen $L$. The amenity value of the urban forest: an application of the hedonic pricing method. Landsc Urban Plan. 1997:37(3):211-22.

90. Tyrväinen $L$, Pauleit $S$, Seeland $K$, de Vries S. Benefits and uses of urban forests and trees. In: Urban Forests and Trees. Berlin Heidelberg: Springer; 2005. p. 81-114

91. McPherson G, Simpson JR, Peper PJ, Maco SE, Xiao Q. Municipal forest benefits and costs in five US cities. J For. 2005;103(8):411-6. 
92. Young RF. Planting the living city: best practices in planning green infrastructure-results from major US cities. J Am Plan Assoc. 2011;77(4):368-81.

93. Banks JC, Brack CL. Canberra's urban Forest: evolution and planning for future landscapes. Urban Forestry Urban Greening. 2003;1(3):151-60.

94. Brack CL. Pollution mitigation and carbon sequestration by an urban forest. Environ Pollut. 2002:116:S195-200

95. Brack CL. Updating urban forest inventories: an example of the DISMUT model. Urban Forestry Urban Greening. 2006:5(4):189-94.

96. Garrard GE, Williams NSG, Mata L, Thomas J, Bekessy SA. Biodiversity sensitive Urban Design. Conserv Lett. 2017. https:/doi.org/10.1111/conl.12411.

97. Watson JEM, Grantham HS, Wilson KA, Possingham HP. Systematic conservation planning: past, present and future. In: Richard JL, Robert JW, editors. Conservation biogeography. London, UK: John Wiley and Sons; 2011. p. 1956-76.

98. Wilson KA, McBride M, Bode M, Possingham HP. Prioritising global conservation efforts. Nature. 2006:440:337-40.

99. Lindenmayer D, Hobbs RJ, Montague Drake R, Alexandra J, Bennett A, Burgman M, Cale P, Calhoun A, Cramer V, Cullen P, Driscoll D, Fahrig L, Fischer J, Franklin J, Haila Y, Hunter M, Gibbons P, Lake S, Luck G, MacGregor C, Mclntyre S, Nally RM, Manning A, Miller J, Mooney H, Noss R, Possingham H, Saunders D, Schmiegelow F, Scott M, Simberloff D, Sisk T, Tabor G, Walker B, Wiens J, Woinarski J, Zavaleta E. A checklist for ecological management of landscapes for conservation. Ecology letters 0, $071010211025003-? ? ? 2007$. https://doi.org/10.1111/j.1461-0248.2007.01114.x.

100. Rudd H, Vala J, Schaefer V. Importance of backyard habitat in a comprehensive biodiversity conservation strategy: a connectivity analysis of urban green spaces. Restor Ecol. 2002;10(2):368-75.

101. Goddard MA, Dougill AJ, Benton TG. Scaling up from gardens: biodiversity conservation in urban environments. Trends Ecol Evol. 2010;25(2):90-8.

102. Ziter $C$. The biodiversity-ecosystem service relationship in urban areas: a quantitative review. Oikos. 2016;125(6):761-8.

103. Gammage B. The biggest estate on earth. Melbourne: Allen and Unwin; 2011.

104. Bartlett AG. Fire management strategies for Pinus radiata plantations near urban areas. Aust For. 2012;75(1):43-53.

105. Pitman AJ, Narisma GT, McAneney J. The impact of climate change on the risk of forest and grassland fires in Australia. Clim Chang. 2007;84(3-4):383-401.

106. Teague B, McLeod R, Pascoe S. Victorian Bushfires Royal Commission Final Report. Melbourne: Parliament of Victoria; 2010.

107. Attiwill PM, Adams MA. Mega-fires, inquiries and politics in the eucalypt forests of Victoria, South-Eastern Australia. For Ecol Manag. 2013;294:45-53. https://doi.org/10.1016/j.foreco.2012.09.015.

108. Cameron PA, Mitra B, Fitzgerald M, Scheinkestel CD, Stripp A, Batey C, Niggemeyer L, Truesdale M, Holman P, Mehra R, Wasiak J. Black Saturday: the immediate impact of the February 2009 bushfires in Victoria, Australia. Med J Aust. 2009;191(1):11-6.

109. Whittaker J, Mercer D. The Victorian bushfires of 2002-03 and the politics of blame: a discourse analysis. Aust Geogr. 2004;35(3):259-87.

110. Gill AM, Stephens SL. Scientific and social challenges for the management of fire-prone wildland-urban interfaces. Environ Res Lett. 2009;4(3):034014.

111. Syphard AD, Massada AB, Butsic V, Keeley JE. Land use planning and wildfire: development policies influence future probability of housing loss. PLoS One. 2013;8:e71708. https://doi.org/10.1371/journal.pone.0071708.

112. Spyratos V, Bourgeron PS, Ghil M. Development at the wildland-urban interface and the mitigation of forest-fire risk. Proc Natl Acad Sci. 2007;104: 14272-6. https://doi.org/10.1073/pnas.0704488104.

113. Agee JK, Skinner CN. Basic principles of forest fuel reduction treatments. For Ecol Manag. 2005;211(1):83-96.

114. Agee JK, Bahro B, Finney MA, Omi PN, Sapsis DB, Skinner CN, Van Wagtendonk JW, Weatherspoon CP. The use of shaded fuelbreaks in landscape fire management. For Ecol Manag. 2000;127(1):55-66.

115. Gibbons P, Van Bommel L, Gill AM, Cary GJ, Driscoll DA, Bradstock RA, Knight E, Moritz MA, Stephens SL, Lindenmayer DB. Land management practices associated with house loss in wildfires. PloS one. 2012;7(1): e29212.

116. Fernandes $P$. Combining forest structure data and fuel modelling to assess fire hazard in Portugal. Ann Forest Sci. 2009;66(4):1-9.

117. Moreira F, Vaz P, Catry F, Silva J. Regional variations in wildfire susceptibility of land- cover types in Portugal: implications for landscape management to minimize fire hazard. Int J Wildland Fire. 2009:18:563-74.
118. Diemer M, Held M, Hofmeister S. Urban wilderness in Central Europe. Int J Wilderness. 2003;9(3):7-11.

119. Navarro LM, Pereira HM. Rewilding abandoned landscapes in Europe. Ecosystems. 2012;15(6):900-12.

120. Schaefer $V$. Alien invasions, ecological restoration in cities and the loss of ecological memory. Restor Ecol. 2009;17(2):171-6.

\section{Publisher's Note}

Springer Nature remains neutral with regard to jurisdictional claims in published maps and institutional affiliations.
Ready to submit your research? Choose BMC and benefit from:

- fast, convenient online submission

- thorough peer review by experienced researchers in your field

- rapid publication on acceptance

- support for research data, including large and complex data types

- gold Open Access which fosters wider collaboration and increased citations

- maximum visibility for your research: over $100 \mathrm{M}$ website views per year

At BMC, research is always in progress.

Learn more biomedcentral.com/submissions 